\title{
Factors Affecting Purchase Intention of Furniture Products: The Case of Wolaita Sodo Town
}

\author{
Temam Lale Saliya \\ Department of Marketing and Sales Management, Wolaita Sodo University, Wolaita Sodo, Ethiopia
}

\begin{abstract}
The main objective of this study was to assess factors affecting consumers purchase intention of furniture products: A case of Wolaita Sodo town. The study was conducted through descriptive and explanatory research design using primary data gathered through questionnaires. Systematic random sampling technique was employed and samples of 385 consumers of furniture product buyers were used to collect the data. However, only 365 consumers responded to the questionnaires and hence, the response rate was 95 percent. Besides, descriptive statistical tools and inferential statistical methods were used to assess the relationships and differences between variables. The value of $\mathrm{R}$ square obtained was 0.786 , demonstrates that 78.6 percent of purchase intention variation can be explained by the independent variables. Based on the statistical analysis, all the variables namely price, product quality, product design, product variety and social influence have a positive relationship with the consumers purchase intention of furniture products.
\end{abstract}

Keywords: Purchase intention, Price, Product Quality, Product Design, Product Variety, Social Influence, Furniture products.

DOI: $10.7176 / \mathrm{JMCR} / 80-02$

Publication date:July $31^{\text {st }} 2021$

\section{INTRODUCTION}

Now a day's competitive and changing business environment that the power of retailers and the customers' demand level is continuously growing, expanding long-term relationship with customers is vital and necessary for the success and survival of producers. Different previous studies have shown that the factors play an important role in purchase intention of furniture products. So Market researchers and organizations spent billions of dollars on consumer research to identify important factors that influence on consumer purchase intention. The people of any countries are sensitive about product or brand and have some questions in their minds such as what the brand offers? And how the product fulfills their needs? Now a day's, the competitive market forced producers to produce goods based on consumer wants and needs (Giovanis, 2013).

Firms can maintain to survive life it can supply consumer needs and demands with a comprehensive understanding of them. This demonstrates the significance of studying consumer behavior (Hawkins, 2006). Therefore, this requires understanding consumer behavior which is not so simple. Consumers may not know their own deeper inner motivation or they may react to affecting factors in the last moment and simply change their mind. However, marketers should consider their customers' requests, intakes and buying behaviors (Kotler, 2010; Solomon, 2006).

In order to assess the factors affecting purchase intention towards furniture products in Ethiopia, this country has more than a hundred year of experience in production of furniture products. Evidences show that growth and development of any economy is highly dependent on industrial development. The economic development of Ethiopia is mainly based on small and medium scale enterprises than the large and sophisticated industries. Ethiopian furniture industry also has to respond to its emerging consumer desires with new products and designs. As the economy continues to show signs of modest recovery, furniture makers are trying to determine the best ways to adjust to these changing consumer demands. This is because Furniture occupies a significant part of every residential environment. Furniture provides a better chance to project self-image with more options and better affordability. So many consumers view their homes and the furniture in them as an extension of themselves (Miller and Matthews, 2013; Coy, 2012).

Consumers buying decision is very complex. Usually purchasing intention is related with consumer's behavior, perception and their attitude. Purchase behavior is an important key point for consumers during considering and evaluating of certain product (Keller, 2001). Ghosh (1990) stated that purchase intention is an effective tool used in predicting purchasing process. Once the consumers decide to purchase the product in certain store, they will be driven by their intention. However, purchase intention might be altered by the influence of different intrinsic and extrinsic factors (Zeithaml, 1998). In addition, consumers will be interrupted by internal impulse and external environment during purchasing process. Their behavior will be driven by the physiological motivation that stimulates their response which brings them to the retail store to fulfill their need (Kim and Jin, 2001).

Thus it is important for furniture manufacturers to go ahead and understand what consumers perceive about their products. In this new marketing era, consumers are the leaders of the market and co-creators. Because of 
this, their perception towards an furniture industry's product very much affects their purchase intention. A company which is aware of the factors that consumers perceive to be important for their purchase decision becomes the market giant and profitable because of its consumer focused insight.

\section{Statement of the Problem}

Individuals have a great deal of choices and options to decide on their needs. In this regard, furniture product manufacturers, uncovering consumers' preferences are predicting consumers' behaviour is the kept to conquer the furniture product market. Though many companies are able to have better products and yet are sometimes unable to compete in the market due to various factors affecting their product market.

There are a few previous studies which are conducted to identify factors affecting purchase intention of furniture products. These studies indicated a range of items as a determinant factor affecting purchase intention.

Prior studies have found that the most important factors affecting consumer's purchase in Jordan furniture which consists of quality, price, reference group, color, and family (Farah, 2013).

Similarly, Yoon and Cho (2009) found that there are eight possible factors influence the consideration of furniture choices which are style, color, price, and construction quality, ease of maintenance, comfort, material, and matching with other items.

Kotler (2003) discussed that the constitutions of product as product variety, product quality, product features, product design, brand name, product size, service, product colour, warranties and returns. In the furniture industry there are 19 factors affecting furniture choice which can be classified into 4 groups; product, service, price, and place. From these the product oriented are, 12 factors include lifelong durability, design, quality, brand, colour, material, comfort, ease of maintenance, ease of cleaning, matching with other items, the size that is suitable for space, and utilization or function. Service group has five factors which are service and installation, after sales service, the personal care for customers, fast service, and product warranty.

There are challenges in the case of furniture manufacturing enterprises that include: poor product quality, short life durability, unattractive colour, difficult to maintenance, unattractive local design, not matching with other item, difficult to cleaning, the size is not suitable for required space, not comfortably, brand problem and its utilization (David, 1998). The manufacturing enterprises which have been using product mix to attract customers may face such obstacles that can hinder them from accomplishment of organizational goals and objectives.

Therefore, the study is going to be conducted and try to find out what are the factors affecting customer purchase intention as well as what challenges it has been facing and finally it should try to fill this gap through further investigation of challenging factors and which of these factors and to what extent each factor affects the purchase intention of furniture products in Wolaita Sodo town.

\section{Objectives of the Study}

\subsection{General Objective}

The general objective of the study was to assess factors affecting purchase intention of furniture products in Wolaita Sodo town.

\section{Review of Related Literature}

Consumer behavior is defined as the behavior that consumers display in seeking, purchasing, using, evaluating and disposing of product and services that they expect will satisfy their personal needs (Schiffman and Kanuk, 2007).

Customer behavior is the process individuals or groups go through to select, purchase, use and dispose of goods, services, ideas or experiences to satisfy their needs and desires (Kotler, P. and Armstrong, G., 2010).

Purchase intention is also defined as the intention of the consumer's to purchase or repurchase the products or goods. The customer is willing and happy to purchase a particular product (Wang and Tadisina, 2006).

Purchase intention means a consumer prefers to buy a product or service because he/she finds that he/she needs a particular product or service, or even attitude towards a product and perception of a particular product. In other words, purchase intention means consumer will buy a product once again after she or he evaluates a product and finds out that the product worth buying. While consumers select one particular product, the final decision on accepting a product to buy or rejecting it depends on consumers' intention. Also, a large number of external factors have been recognized, which can affect the consumer purchase intention (Keller, 2001).

A customer uses price to indicate the quality or benefit of brand, this means that the price plays a role in purchasing a brand because a customer can choose a lower price to prevent financial risk or choose a higher price to achieve product quality (MacDonald \& Sharp, 2000).

Product quality is one of the factors that affecting the customer purchase intention and it is the overall characteristics of a product that allow it to perform as expected in satisfying customer needs (Jean F, 2004).

According to Golnesa Ahimadi (2013), the design of packaging of any product attracts any consumers and 
persuades them to purchase that product.

Product variety has a greater importance on promoting the brands of the marketers extensively and the decision of consumers. We can see that product variety is one of the predictor to buy a product. However, to increases the possibility of finding the product they need the customers mostly need a greater variety of the product in the market (Kotler, 2003).

Aaronson (2004), social influence is the effect that people have up on the beliefs or behaviors of others.

\section{Conceptual Framework of Research}

Many researchers agree that the following variables are determines customers purchase intention of furniture products. On the basis of literature review and previous studies conceptual framework was developed.

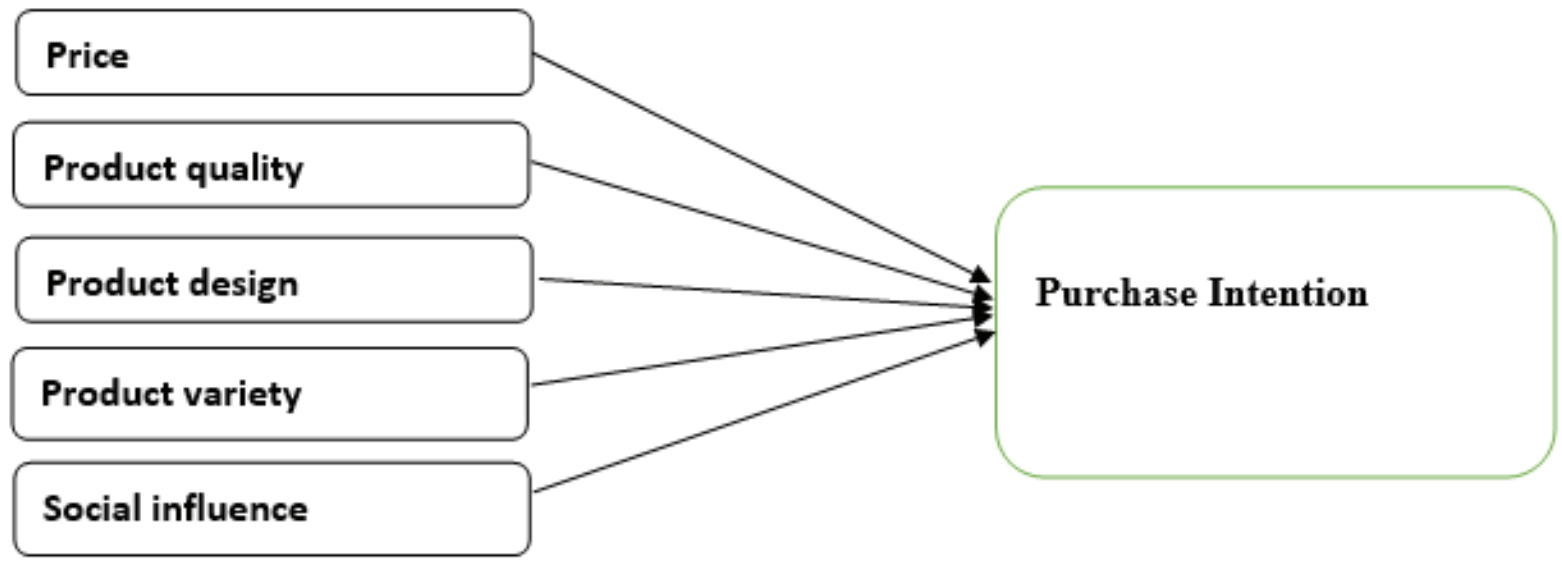

\section{Hypotheses of study}

Ho1: Price has no statistically significant effect on consumers' purchase intention of furniture products in Wolaita Sodo town.

Ho2: Product quality has no statistically significant effect on consumers' purchase intention to buy furniture products in Wolaita Sodo town.

Ho3: Product design has no statistically significant effect on consumers' purchase intention to buy furniture products in Wolaita Sodo town.

Ho4: Product variety has no statistically significant effect on consumers' purchase intention to buy furniture products in Wolaita Sodo town.

Ho5: Social influence has no statistically significant effect on consumers' purchase intention to buy furniture products in Wolaita Sodo town.

\section{RESEARCH METHODOLOGY}

This research was employed both explanatory and descriptive research design by using cross sectional survey strategy which was data collected at one point of time from sampled population to give generalization to target under study. According to Mark et al. (2009:101) mixing qualitative and quantitative approaches gives the potential to cover each methods weaknesses with strengths from the other method. In this study, a combination of qualitative and quantitative approaches of doing research was employed, which has been practiced, as recommended by Creswell (2009:203-216). Primary data was collected using questionnaire through enumerator administered schedules. The questions that were used in the questionnaire were five point likert scale type questions. The type of scales used to measure the items on the instrument is continuous scales (strongly agree to strongly disagree). The secondary data collected from various documents of the enterprises, articles, journals, internet, books as well as Wolaita zone Trade and Industry department with document investigation that have relevance with the research topic. More over the study used a Pearson correlation analysis to test the hypothesis drawn and their relationship, fatherly multiple linear regression analysis was used to test the effect of independent variables on the ppurchase intention of furniture products and to rank the identified factors.

The study population was mainly composed of all furniture product customers found in Wolaita Sodo town. The target populations for this study was residents of Wolaita Sodo town who were customers those who are involved in purchasing of furniture products.. However, since the number of furniture product purchasing customers is unknown and infinite. To determine the appropriate sample size the population is very large or infinite and proportion of mutually exclusive cases is unknown. So the scientific method was applied to determine the sample size for unlimited number of population is the formula of Cochran (1977). At 95\% confidence level the maximum value rate of p. $\mathrm{q}$ is taken to be $25 \%$ from $50 \%$ of p and $50 \%$ of q. the value of $\mathrm{z}$ 
is 1.96 , which is the value of selected alpha level. The formula will be:

$$
n=\frac{z^{2} p \cdot q}{e^{2}}=\frac{(1.96)^{2}(0.25)}{(0.05)^{2}} \approx 385
$$

Thus, 385 people were taken as samples for this study.

To achieve purpose of study, this research was employed both convenience and systematic random sampling techniques had been used in this study.

The primary instrument for data collection in this research was designed through structured questionnaire, which consists of closed-ended questions with five point Likert scale statements. Questionnaires has been developed based on literature review of related topics in factors affecting consumers purchase intention of furniture products.

To assure reliability and validity of questionnaire, questionnaire has been pre-tested on a small sample of 20 furniture product consumers live in Wolaita Sodo town.Questionnaire has been distributed to sample of 385 consumers of furniture products and data has been collected within days of September 15, 2018 to October 4, 2018.

Zikmund et al. (2010), suggested that scales with coefficient alpha between 0.6 and 0.7 has fair reliability for further analysis. To assure that data reliable and consistent, Cronbach's alpha coefficients test has been done. The test revealed that price has $(0.935)$, product quality $(0.935)$, product design $(0.839)$, product variety $(0.818)$, social influence (0.893) and purchase intention (0.835) which indicate the instruments are reliable and acceptable for further data analysis. In order to ensure the content validity discussion with experts in study areas has been made.

After data had been collected, coded, screened and processed, data analyses were made by using both descriptive, correlation, multiple linear regression models, independent sample t-test and one way ANOVA was done. Multivariate data assumptions test has been done and acceptable results found for linearity, Collinearity, normality and homoscedacity. Descriptive statistics have been employed, to analyze data that related to demographic profile of respondents, correlation coefficient has been employed to show the interdependence between the five explanatory variables; price, product quality, product design, product variety, and social influence and dependent variables that is purchase intention. Multiple linear Regression analysis was used to test the significance contribution of each independent variable to the dependent variable purchase intention and independent sample t-test and one way ANOVA has been employed to examine relationship between underlying factors of consumers purchase intention and demographic profiles of respondents.

\section{Results and Findings}

Descriptive analysis Summary

The descriptive analysis of dependent and independent variables is summarized and indicated here below.

Table 1: Descriptive analysis summary

\begin{tabular}{|l|l|l|l|l|l|}
\hline S. No & Variables & No. of Items & N & Grand Mean & Std. Deviation \\
\hline 1 & Price & 6 & 365 & 3.9694 & 0.6630 \\
\hline 2 & Product quality & 6 & 365 & 4.0205 & 0.72279 \\
\hline 3 & Product design & 4 & 365 & 3.9610 & 0.7286 \\
\hline 4 & Product variety & 5 & 365 & 3.9655 & 0.7054 \\
\hline 5 & Social influence & 5 & 365 & 3.920 & 0.6798 \\
\hline 6 & Purchase intention & 5 & 365 & 3.8805 & 0.58157 \\
\hline & Valid N (List wise) & & 365 & & \\
\hline
\end{tabular}

Source: survey data, 2018

Based on the above table1, the findings from the descriptive statistics on variables of the study, purchase intention has the least mean of all (i.e. 3.8805) the next mean values are $(3.9200,3.9651,3.9655,3.9694$, and 4.0082) for social influence, product design, product variety, price, and product quality respectively). The summary of the independent variables in which the mean score values ranges from 3.4 to 4.2 , which implies that the majority of the respondents agreed with the five independent variables (price, product quality, product design, product variety and social influence) are important factors for customers in order to make for purchase intention of furniture products in the study area. 
Table 2: Results showing correlation analysis

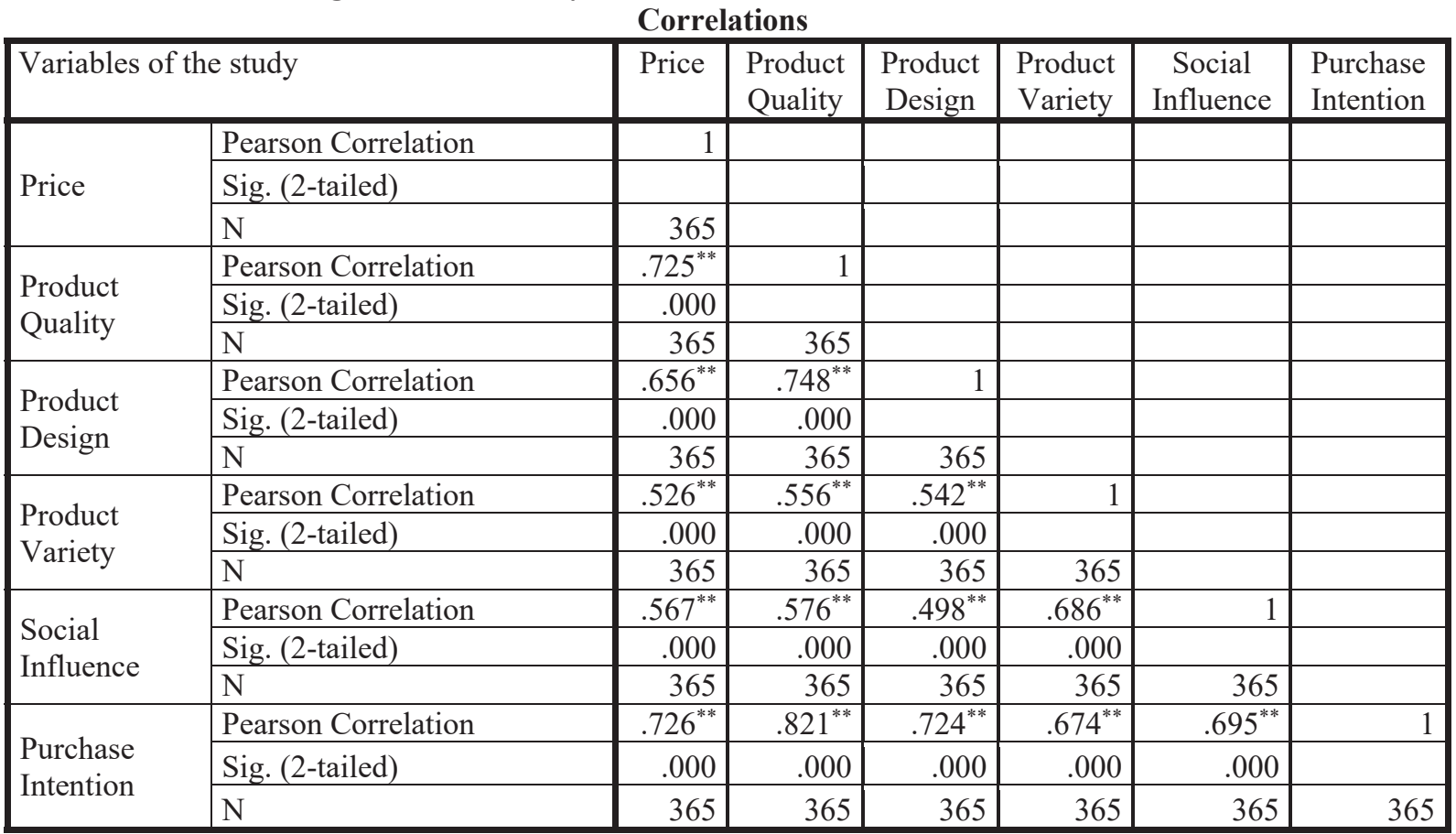

**. Correlation is significant at the 0.01 level (2-tailed).

Source: SPSS output of own survey, 2018

Summary: based on the above five correlation analysis the basic question that what is the relationship between each factors and purchase intention? is answered. Therefore, five factors (price, product quality, product design, product variety and social influence) have a significant positive correlation with purchase intention. With regard to the magnitude of the correlation, four factors (product price, product design, product variety and social influence) have strong correlation with purchase intention and the remaining one (product quality) has very strong correlation with purchase intention.

Table 3: Results showing regression analysis

\begin{tabular}{|l|r|r|r|r|}
\hline Model & R & \multicolumn{1}{|c|}{ R Square } & Adjusted R Square & Std. Error of the Estimate \\
\hline 1 & $.887^{\mathrm{a}}$ & .786 & .783 & .27061 \\
\hline
\end{tabular}

a. Predictors: (Constant), Social Influence, Product Design, Product Variety, Price, Product Quality

b. Dependent Variable: Purchase Intention

Source: SPSS output from own survey data, 2018

The result shows that a value of $\mathrm{R}$ square is .786 which implies that 78.6 percent variation was caused by the considered independent variables. $.786 \mathrm{R}$ square value means that the total variation in the dependent variable is explained or caused by 78.6 percent of the change in all independent variables: variables price, product quality, product design, product variety, social influence. The remaining $21.4 \%$ variations on purchase intention of furniture products were explained by other variables.

Table 4: Results showing analysis of Variance (ANOVA) of Regression Analysis

ANOVA $^{\mathrm{a}}$

\begin{tabular}{|ll|r|r|r|r|r|}
\hline Model & & Sum of Squares & df & Mean Square & F & Sig. \\
\hline \multirow{3}{*}{1} & Regression & 96.823 & 5 & 19.365 & 264.441 & $.000^{\mathrm{b}}$ \\
& Residual & 26.289 & 359 & .073 & & \\
& Total & 123.112 & 364 & & & \\
\hline
\end{tabular}

a. Dependent Variable: Purchase Intention

b. Predictors: (Constant), Social Influence, Product Design, Price , Product Variety, Product quality

Source: SPSS output from own survey data, 2018

In general, the above ANOVA table shows a strong relationship between the dependent and independent variables of the study with F-statistic or F-ratio of 264.441 for the overall analysis, and is worth-mentioning that the F-value is highly significant (as $\mathrm{p}=.000<.01$ ). Hence, model was significant, there were linear relationship in multiple regressions and it indicates that the variation explained by the model. 
Table 5: Results showing coefficient of regression analysis Coefficients $^{\mathbf{a}}$

\begin{tabular}{|c|c|c|c|c|c|c|}
\hline \multirow{2}{*}{\multicolumn{2}{|c|}{ Model }} & \multicolumn{2}{|c|}{ Unstandardized Coefficients } & \multirow{2}{*}{$\begin{array}{c}\text { Standardized } \\
\text { Coefficients } \\
\text { Beta }\end{array}$} & \multirow[t]{2}{*}{$\mathrm{T}$} & \multirow[t]{2}{*}{ Sig. } \\
\hline & & $\mathrm{B}$ & Std. Error & & & \\
\hline & (Constant) & .432 & .099 & & 4.356 & .000 \\
\hline & Price & .122 & .033 & .139 & 3.680 & .000 \\
\hline & Product Quality & .332 & .034 & .413 & 9.670 & .000 \\
\hline 1 & Product Design & .110 & .031 & .137 & 3.556 & .000 \\
\hline & Product Variety & .131 & .029 & .159 & 4.479 & .000 \\
\hline & Social Influence & .172 & .031 & .201 & 5.580 & .000 \\
\hline
\end{tabular}

a. Dependent Variable: Purchase Intention

Source: SPSS output from own survey data, 2018

According to table 5, coefficient of regression shown between independent variables price, product quality, product design, product variety, social influence and a dependent variable purchase intention.

The beta values tell what degree each independent variable affects the outcome if the effects of all other predictors are held constant. Each of the beta values has an associated standard error indicating to what extent these values would vary across different samples, and these standard errors are used to determine whether or not beta value differ significantly from zero. The t-test associated with b-value is significant (if the value in the column labeled Sig. is less .05) then the predictor is making significant contribution to the model. The smaller the value of the sign (the larger the value of $t$ ), the greater contribution of that predictor. For this model, price $(t$ $(359)=3.680, \mathrm{p}<.05)$, product quality $(t(359)=9.670, \mathrm{p}<.05)$, product design $(t(359)=3.556, \mathrm{p}<.05)$, product variety $(t(359)=4.479, \mathrm{p}<.05)$, and social influence $(t(359)=5.580, \mathrm{p}<.05)$.

The following hypotheses were tested using multiple regression analysis to know if there is an effect of independent variables on the dependent variable. According to the decision rule: accept the null hypothesis (Ho) if the significance level of the variable is greater than the (0.05) significance level, reject (Ho) if the significance level of the variable is equal or less than (0.05) (Sekaran, 2004). According to the previous decision rule, the researcher has tested the proposed hypotheses and found the following results:

Results showed that there was a statistically significant effect for five independent variables (price, product quality, product design, product variety and social influence) on the dependent variable (purchase intention).

\section{Beta coefficient}

\section{Unstandardized Beta Coefficient}

By recalling the model specifications of the variables from the chapter three of methodology part, it was said that, the unstandardized coefficients $(\boldsymbol{\beta} 1$ up to $\boldsymbol{\beta} 5)$ are the coefficients of the estimated regression model. Hence, the model of purchase intention can be written by including error term $(\mathcal{E})$, in the below form.

$\mathrm{Y}=\beta 0+\beta 1 X 1+\beta 2 \mathrm{X} 2+\beta 3 \mathrm{X} 3+\beta 4 \mathrm{X} 4+\beta 5 \mathrm{X} 5+\varepsilon$

Where, $\mathrm{Y}=$ Dependent Variable (purchase intention)

$\beta 1=$ unstandardized regression coefficient of price

$\beta 2=$ unstandardized regression coefficient of product quality

$\beta 3=$ unstandardized regression coefficient of product design

$\beta 4=$ unstandardized regression coefficient of product variety

$\beta 5=$ unstandardized regression coefficient of social influence

$\varepsilon=$ error term

Taking in to consideration the results from table 4.16, the regression equation for the study was as follows:

$\mathrm{Y}=.432+.122 \mathrm{X} 1+.332 \mathrm{X} 2+.110 \mathrm{X} 3+.131 \mathrm{X} 4+.172 \mathrm{X} 5+.099$

$\mathrm{PIFP}=.432+.122 *$ Price $+.332 *$ Product Quality $+.110 *$ Product Design $+.131 *$ product Variety $+.172 *$

Social Influence +0.99

\section{Interpretation:}

Keeping all other variables Constant; for every one-unit increment on price of furniture products, the percentage of purchase intention increases by 12.2 (percent), for every one-unit increment on product quality of furniture products, the percentage of purchase intention increases by 33.2 (percent), for every one-unit increment on product design of furniture products, the percentage of purchase intention increases by 11.0 (percent), for every one-unit increment on product variety of furniture products, the percentage of purchase intention increases by 13.1 (percent) and for every one-unit increment on social influence of the furniture products, the percentage of purchase intention increases by 17.2 (percent).

From the regression equation, the constant value $\beta_{0}=.432$ implies that, if the independent variables afore 
mentioned in this study are kept constant as they exist or make them unavailable, the purchase intention of the furniture product would be less. This shows that the independent variables are vital for the growth and improvements of the furniture products purchase intention.

Hypothesis Testing and Discussion.

Hypothesis Testing

Hypothesis testing is the method of testing whether claims or hypothesis regarding a population are likely to be true. The goal of hypothesis testing is to determine the likelihood that a population parameter. Here there are two hypotheses: null (Ho), and alternative (Ha). The significance (sig.) value expresses a value to accept or reject the (null) hypothesis. It is also called the P-value. The P-value is the probability that the correlation is one just by chance. Therefore, the smaller the P-value, the better will be. The general rule is reject Ho if $\mathrm{P}<.05$ and accept Ho if $\mathrm{P} \geq .05$ (Pallant, 2016).

In this part of the study, proof of the null hypothesis is made based on table 5 above the variables. Because, to test the research hypothesis already set in chapter one, it is possible to find out if the independent variables are significant predictors of the dependent variable. To test these relationships, the regression analysis was applied.

\section{Hypothesis 1:}

Ho1: price has no statistically significant effect on consumers' purchase intention of furniture products in Wolaita Sodo town.

Price does not have a statistically significant effect on towards consumer's furniture product buying intention. (Reject Hol if $\mathrm{p}<0.05$ ) otherwise accept it. From table 5, the significant value for price is 0.000 which is less than $\mathrm{p}$ value of 0.05 . Therefore, Ho1 is rejected, which indicates that price has statistically significant effect on consumer's purchase intention of furniture products.

Besides, the value of beta for price is $(\beta=.122)$ this shows that price has positive and significant effect on towards consumer's furniture product buying intention. Hence, the above proposed hypothesis is rejected and the alternative hypothesis is accepted. This indicates that price has statistically significant effect on consumers' purchase intention of furniture products in Wolaita Sodo town.

Hypothesis 2:

Ho2: Product quality has no statistically significant effect on consumers purchase intention to buy furniture products in Wolaita Sodo town.

Product quality does not have a statistically significant effect on towards consumer's furniture product buying intention. (Reject Ho2 if $\mathrm{p}<0.05$ ) otherwise accept it. From table 5, the significant value for product quality is 0.000 which is less than $\mathrm{p}$ value of 0.05 . Therefore, Ho2 is rejected, which indicates that product quality has a statistically significant effect on consumer's purchase intention of furniture products.

Besides, the value of beta for product quality is $(\beta=.332)$ this shows that product quality has positive and significant effect on towards consumer's furniture product buying intention. Hence, the above proposed hypothesis is rejected and the alternative hypothesis is accepted. This indicates that product quality has a statistically significant effect on consumer's purchase intention of furniture products in Wolaita Sodo town.

Hypothesis 3:

Ho3: Product design has no statistically significant effect on consumers purchase intention to buy furniture products in Wolaita Sodo town.

Product design does not have a statistically significant effect on towards consumer's furniture product buying intention. (Reject Ho3 if $\mathrm{p}<0.05$ ) otherwise accept it. From table 5, the significant value for product design is 0.000 which is less than $\mathrm{p}$ value of 0.05 . Therefore, Ho3 is rejected, which indicates that product design has a statistically significant effect on consumer's purchase intention furniture products.

Besides, the value of beta for product quality is $(\beta=.110)$ this shows that product design has positive and significant effect on towards consumer's furniture product buying intention. Hence, the above proposed hypothesis is rejected and the alternative hypothesis is accepted. This indicates that product design has a statistically significant effect on consumer's purchase intention of furniture products in Wolaita Sodo town.

Hypothesis 4:

Ho4: Product variety has no statistically significant effect on consumers purchase intention to buy furniture products in Wolaita Sodo town.

Product variety does not have a statistically significant effect on towards consumer's furniture product buying intention. (Reject Ho4 if $\mathrm{p}<0.05$ ) otherwise accept it. From table 5, the significant value for product variety is 0.000 which is less than $p$ value of 0.05 . Therefore, Ho4 is rejected, which indicates that product variety has a statistically significant effect on consumer's purchase intention of furniture products.

Besides, the value of beta for product variety is $(\beta=.131)$ this shows that product variety has positive and significant effect on towards consumer's furniture product buying intention. Hence, the above proposed hypothesis is rejected and the alternative hypothesis is accepted. This indicates that product variety has a statistically significant effect on consumer's purchase intention to buy furniture products in Wolaita Sodo town. 


\section{Hypothesis 5:}

Ho5: Social influence has no statistically significant impact on consumers purchase intention to buy furniture products in Wolaita Sodo town.

Social influence does not have a statistically significant impact on intention to buy furniture product. (Reject Ho5 if $\mathrm{p}<0.05$ ) otherwise accept it. From table 5, the significant value for Social influence is 0.000 which is less than $\mathrm{p}$ value of 0.05 . Therefore, Ho5 is rejected, which indicates that Social influence has a statistically significant impact on purchase intention to buy furniture products in Wolaita Sodo town.

Besides, the value of beta for Social influence is $(\beta=.172)$ this shows that Social influence has positive and significant impact on intention to buy furniture products. Hence, the above proposed hypothesis is rejected and the alternative hypothesis is accepted. This indicates that Social influence has a significant effect on consumers purchase intention to buy furniture products in Wolaita Sodo town.

\section{Conclusions}

During the investigation the researcher used both descriptive and inferential statistics and based on the findings of the research the researcher made conclusions by outlining following points.

As the results of the descriptive statistics depicted majority of the respondents agreed with the five independent variables (price, product quality, product design, product variety and social influence) are important factors for customers in order to make for purchasing their furniture products in the study area.

The Pearson's correlation result of the analysis showed that, all five factors (price, product quality, product design, product variety and social influence) have a significant positive correlation with purchase intention. With regard to the magnitude of the correlation, four factors (price, product design, product variety and social influence) have strong correlation with purchase intention and the remaining one (product quality) has very strong correlation with purchase intention.

The pre-model fitting five assumptions (i.e., normality of distribution, linearity, multicollinearity of the variables, homoscedasticity, and independence of residuals) of multiple regressions are met accordingly. Furthermore, the multiple linear regression analysis (The R square) implies that about 78.6 (percent) shows that the five independent variables (price, product quality, product design, product variety and social influence) can determine the variation of purchase intention of furniture products. Therefore, the researcher can convincingly conclude that the study factors have a significant influence on purchase intention of furniture products.

As far as the relative effects of an individual component of independent factors on dependent variable (purchase intention) is concerned, the result of multiple linear regression coefficient shows that product quality factors have the highest beta value which indicates the most dominant effect on consumers purchase intention of furniture product followed by social influence factors, product variety factors, price factors and product design factors with a beta values of $(\beta=0.172, \beta=0.131, \beta=0.122$ and $\beta=0.110)$ respectively.

The multiple linear regression analysis of the independent variables and dependent variables shows that five explanatory variables (price, product quality, product design, product variety and social influence) have a statistically significant effect for predicting purchase intention of furniture products.

Finally it is possible to conclude that all independent variables (price, product quality, product design, product variety and social influence) affect purchase intention of furniture products significantly and needs to give high emphasis to the listed independent variables to attract more customers and to increase purchase of furniture products.

\section{Recommendations}

The study has to provide some significant knowledge and information to the furniture product manufacturers as well as marketers to uncover consumers' intention in order to anticipate consumers buying behavior and surmount the furniture product market in Wolaita Sodo town. In this study five independent variables (price, product quality, product design, product variety and social influence) were identified that affect consumers purchase intention of furniture products in Wolaita Sodo town. However, not necessarily all the variables influence consumers in the same extent. Based on the research findings the following possible recommendations are forwarded:

$>$ According to the study results, Product quality was the most important factor influencing furniture choice of customers. There are many elements that build up the quality of furniture such as raw material, good look \& color, comfort and matching with other items. Therefore, the manufacturers would like to increase the quality of furniture in order to capture consumers' interest. So the researcher recommends that the furniture manufacturers should produce furniture product with good quality image.

$>$ According to the study results, price was the most important factors concerning by customers when purchasing furniture products. Furniture industry has a wide range of customers from low income to high income. Thus, set up multiple price range of furniture product is recommended to consumers in order to respond the various customers need. 
$>$ Product design is also other major determining factor in influencing consumers purchase intention of furniture products. The manufacturers of furniture product had to give more attention for the designs of furniture products which suits the fashion. For instance, the modern design has a tendency to be well received by the customers. Therefore, furniture product manufacturers and marketers should give emphasis to the design of the furniture product.

$>$ The fourth factor that affects furniture product purchase intention is social influence. Social influence has a significant impact on furniture product consumers purchase intention, when consumers are referring to friends, family, colleagues, professionals and sales personnel's. Therefore, furniture product manufacturers and marketers should strive to create a positive word of mouth among consumers. This in turn, enables manufacturers and marketers to have a wider audience.

$>$ In a highly competitive market, a product variety becomes one of the most imperative factors in gaining competitive advantage among competitors. Thus, a wide range of product is important since customers' value variety when purchasing furniture products. Therefore, it is important for the furniture product manufacturers to have a variety of products.

$>$ Furniture manufacturing enterprises and marketing managers should identify their target customers and understand their demographics characteristics in developing successful furniture product strategies.

\section{REFERENCES}

Bhattacherjee, A. (2012). Social Science Research: principle, methods, and practices. University of South Florida: Scholar Commons.

Cochran. W.G. (1997). Sampling Techniques ( $3^{\text {rd }}$ ed.). Harvard University.

Creswell, J. (2003). Research Design: Qualitative Quantitative and Mixed Methods Approaches (2 ${ }^{\text {nd }}$ ed.). California: Sage publications.

David, B.F. (1998).Intermediate Business: Theories and Practices. (4 ${ }^{\text {th }}$ ed.).London; MacMillan Press Ltd.

Farah, N. (2013).Multifunctional furniture for underprivileged communities: milestone in sustainable development, publish thesis, Purdue University.

Giovanis, A., Tomaras, P., Zondiros, D.(2013), Suppliers Logistics Service Quality Performance and its Effect on Retailers' Behavioral Intentions, The 2nd International Conference on Integrated Information, Social and Behavioral Sciences, 73, $302-309$.

Hawkins, D. Best, R. \& Coney, K.(2006).Consumer behavior, compilation of the marketingstrategy, translated by Ahmad Roosta \& Atiyeh Botahi, Sargol publication, Tehran.

Keller, K. L. (2001). Building customer-based brand equity: creating brand resonance requires carefully sequenced brand-building efforts, Marketing Management, Vol: 10(2).

Kim, E. Y., \& Kim, Y. K. (2004). Predicting online Purchase intentions for Clothing Products. European Journal of Marketing, Vol: (38(7), PP. $883-897$.

Kothari, C., R. (2004). Research Methodology: Methods and Techniques(2 ${ }^{\text {nd }}$ Revised ed.). India: New Age International Publishers.

Kotler, P. (2003). Marketing Management, Prentice Hall of India, New Delhi, ISBN - 81-203-2083-2.

Kotler,P. and Armstrong,G. (2008).Principles of Marketing and Management in manufacturing Enterprises (2 ${ }^{\text {nd }}$ ed.). Eagle wood Cliffs: New Jersey.

Kotler, P. \& Armstrong, G. (2010). Principle of Marketing (13 $3^{\text {th }}$ ed.). Boston: Pearson Education.

Kotler, P. \& Armstrong, G. (2012). Principle of Marketing (14 ${ }^{\text {th }}$ ed.). New York: Pearson Prentice Hall.

Kotler, p. \& Keller, K. (2006). Marketing Management (12 $2^{\text {th }}$ ed.). Upper Saddle River, New Jersey: York: Pearson Education, Inc.

MacDonald, E. k., \& Sharp, B. M. (2000). Brand Awareness Effects on consumer Decision Making for a common, repeat purchase product: A Replication Journal of Business Research, PP. 5 - 15.

Mark, S., Philip, L., \& Adrian, T. (2009). Research Methods for Business Students (5 ${ }^{\text {th }}$ ed.). Rotolito Lombarda, Italy.

Miller, Rich and Steve Matthews (2013).The Long, Slow, but Still-Going Recovery, Bloomberg Business week, June 10, 49-51.

Muluadam. (2015). Introduction to SPSS for windows, Version 20. A Training Manual (PPT). AAU, Ethiopia: Public Policy \& Management FBE.

Schiffman, L. G., \& Kanuk, L. L. (2007). Consumer Behavior (9 $9^{\text {th }}$ ed.). NJ: Prentice-Hall Inc.

Solomon, M. (2006). Consumer Behavior: A European Perspective (3 ${ }^{\text {rd }}$ ed.). Harlow: Prentice Hall.

Yoon, So-Yeon. \& Cho, JiYoung (2009). Understanding Furniture Decision Making Process and Design Preference Using Web-Based VR Technology, St. Louis, Missouri, 25-28.

Zeithaml V A. (1998). Consumer Perceptions of Price, Quality and Value: a Means-end Model 